\title{
ANALISIS PROSEDUR PENERIMAAN PASIEN RAWAT JALAN GUNA MENUNJANG EFEKTIVITAS PELAYANAN REKAM MEDIS DI PUSKESMAS SUDI
}

\author{
Inggriani Tigrid $^{1}$, Meira Hidayati ${ }^{2}$ \\ Fakultas Kesehatan Prodi Rekam Medis dan Informasi Kesehatan Politeknik Piksi Ganesha, Bandung, Indonesia

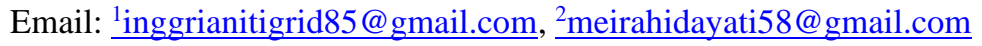

\begin{abstract}
Abstrak
Berdasarkan hasil studi pendahuluan di Puskesmas Sudi dalam proses penerimaan pasien rawat jalan untuk pencarian nomor rekam medis pasien yang tidak membawa kartu berobat pada saat pendaftaran sehingga tidak efektif dalam pelayanan penerimaan pasien di Puskesmas Sudi. Metode penelitian ini adalah penelitian kualitatif, subjek dalam penelitian ini adalah petugas penerimaan pasien rawat jalan yaitu petugas rekam medis. Metode pengumpulan data penelitian ini adalah observasi di Puskesmas Sudi dengan checklist dan wawancara tidak terstruktur. Pengolahan data berupa penyusunan data, yang kemudian analisa data akan diolah secara deskriptif untuk menganalisa faktor penyebab penerimaan pasien rawat jalan tidak efektif. Hasil penelitian kualifikasi dari identifikasi jumlah pasien yang tidak membawa kartu berobat saat mendaftar dibagian pendaftaran rawat jalan yaitu yang dilihat dari faktor manusianya yaitu kurangnya komunikasi antara perekam medis dengan kepala puskesmas sehingga kurang di perhatikannya pelayanan di bagian penerimaan pasien oleh petugas puskesmas dan kurangnya pemahaman pasien atas penjelasan petugas. Kesimpulan penelitian ini dilihat dari identifikasi 5M yaitu faktor man dan method meliputi kurangnya tenaga kesehatan untuk mengoprasikan bentuk KIB baru, kurangnya pemahaman kepada pasien dan kurangnya petunjuk alur pendaftaran pasien.
\end{abstract}

Kata kunci: nomor rekam medis; kartu berobat; penerimaan pasien rawat jalan

\begin{abstract}
Based on the results of a preliminary study at the Sudi Health Center in the process of accepting outpatients to search for the medical record number of patients who did not carry a medical card at the time of registration so that it was not effective in receiving patient services at the Sudi Health Center. This research method is a qualitative research, the subject in this study is an outpatient admission officer, namely a medical record officer. The method of data collection in this study was observation at the Sudi Health Center with a checklist and unstructured interviews. Data processing is in the form of data compilation, which will then be processed descriptively to analyze the factors causing ineffective outpatient admissions. The results of the qualification research were identified from the identification of the number of patients who did not carry a medical card when registering at the outpatient registration section, which was seen from the human factor, namely the lack of communication between the medical recorder and the head of the puskesmas so that less attention was paid to services at the patient reception by puskesmas officers and the lack of patient understanding of officer explanation. The conclusion of this study is seen from the identification of 5M, namely the man and method factors including the lack of health workers to operate the new form of $\mathrm{MNH}$, lack of understanding to patients and lack of instructions for patient registration flow.
\end{abstract}

\section{Keywords: medical record number; medical card; outpatient admission}




\section{Pendahuluan}

Pelayanan Kesehatan adalah konsep yang digunakan dalam memberikan pelayanan kesehatan kepada masyarakat guna meningkatkan pencegahan dan penyembuhan suatu penyakit. Dan setiap upaya yang diselenggarakan untuk memelihara, mencegah, menyembuhkan, penyakit dan meningkatkan kesehatan terutama masyarakat yang memerlukan pelayanan kesehatan seperti adanya Pusat Kesehatan Masyarakat (Puskesmas).

Berdasakan Permenkes No.75 tahun 2014 tentang puskesmas. Pusat Kesehatan Masyarakat (Puskesmas) ialah fasilitas pelayanan kesehatan tingkat pertama yang menyelenggarakan upaya kesehatan masyarakat dan upaya kesehatan perseorangan tingkat pertama, dengan lebih mengutamakan upaya promotif dan preventif untuk mencapainya derajat kesehatan masyarakat setinggi-tingginya di wilayah kerjanya.

Puskesmas merupakan ujung tombak dari peranan pemerintah dalam menyelenggarakan pelayanan kesehatan dasar yang baik bagi masyarakat luas, Puskesmas mempunyai wewenang dan tanggung jawab atas pemeliharaan kesehatan masyarakat dalam tanggung jawab wilayah kerjanya. Dalam penyelenggaraan Pusat Kesehatan Masyarakat diperlukan ahli kesehatan, salah satunya yaitu perekam medis.

Menurut PERMENKES RI No.269/MENKES/PER/III/2008 Rekam Medis ialah berkas yang berisikan catatan dan dokumen tentang identitas pasien, pemeriksaan, tindakan dan pelayanan lain yang telah diberikan kepada pasien.

Rekam medis yaitu keterangan baik yang tertulis atau yang terekam tentang identitas, anamnesis penentuan fisik laboratorium, diagnose segala pelayanan dan tindakan medik yang diberikan kepada pasien dan pengobatan yang dirawat inap, rawat jalan ataupun yang mendapatkan perawatan gawat darurat. Dalam pelayanan rekam medis ada rekam medis manual dan rekam medis elektronik.

Puskesmas telah memberlakukan rekam medis elektronik, rekam medis elektronik adalah penggunaan perangkat teknologi informasi untuk pengumpulan penyimpanan, pengolahan serta pengakses-an data yang tersimpan pada rekam medis pasien dalam sistem manajemen berbasis data yang menghimpun sumber data medis. Dan di Puskesmas telah menggunakan Sistem Informasi Puskesmas (SIMPUS).

Sistem informasi kesehatan ialah prosedur yang dimulai dari penghimpunan data, penggarapan data, pengkaian dan pertukaran informasi yang diperlakukan untuk mengelola dan mengendalikan yankes serta digunakan untuk keperluan penelitian serta untuk pelatihan.

Tujuan rekam medis adalah untuk menunjang tercapainya tertib administrasi dalam rangka upaya peningkatan pelayanan kesehatan, tanpa dukungan suatu sistem pengelolaan pelayanan rekam medis yang baik dan benar, tidak akan tercapai administrasi sesuai dengan yang diharapkan, tertib administrasi merupakan salah satu faktor yang menentukan upaya pelayanan kesehatan. 
Adapun kegiatan rekam medis dimulai dari proses penerimaan pasien di Tempat Penerimaan Pasien Rawat Jalan (TPPRJ). Penerimaan pasien terdapat prosedur penerimaan khususnya dibagian rawat jalan yaitu pasien baru dan pasien lama, setelah dilakukan observasi di Puskesmas Sudi ditemukan pasien yang tidak membawa Kartu Indeks Berobat (KIB) sehingga menghambat proses penerimaan pasien rawat jalan dibagian pendaftaran sehingga tidak efektif dalam pelayanan penerimaan pasien rawat jalan di Puskesmas Sudi Kab. Bandung

Berdasarkan pemaparan diatas, maka rumusan masalah dalam penelitian ini adalah untuk mengetahui faktor apa saja yang menghambat penerimaan pasien dibagian pendaftaan sehingga tidak efektif dalam pelayanan penerimaan pasien rawat jalan di Puskesmas Sudi Kab.Bandung.

\section{Metode Penelitian}

Jenis metode penelitian ini ialah penelitian kualitatif, yaitu prosedur penelitian yang menghasilkan data deksriptif berupa kata-kata tertulis atau lisan dari orang-orang dan perilaku yang dapat diamati, (Bogdan\&Tailor,1995). Subjek dalam penelitian ini adalah petugas penerimaan pasien rawat jalan yaitu petugas rekam medis dan pasien di Puskesmas Sudi. Metode pengumpulan data penelitian ini adalah observasi di Puskesmas Sudi dengan checklist dan wawancara tidak terstruktur. Pengolahan data berupa penyusunan data, yang kemudian analisa data akan diolah secara deskriptif untuk menganalisa faktor penyebab penerimaan pasien rawat jalan tidak efektif.

\section{Hasil dan Pembahasan}

Puskesmas Sudi menerapkan sistem penomoran secara Unit Numbering System, yaitu sistem penomoran dimana sistem ini memberikan satu nomor rekam medis pada pasien berobat jalan, pasien rawat inap, gawat darurat dan bayi baru lahir.

Selain itu, Puskesmas Sudi menerapkan sistem penyimpanan secara Family folder, yang merupakan sarana untuk merekam (menyimpan) data keluarga dan data individu keluarga. Data keluarga meliputi komponen rumah sehat. Dan data individu anggota keluarga mencantumkan karakteristik individu meliputi: umur, jenis kelamin, alamat dan lain-lain.

Berikut adalah alur penerimaan pasien rawat jalan dan alur petugas rekam medis di Puskesmas Sudi Kab.Bandung : 


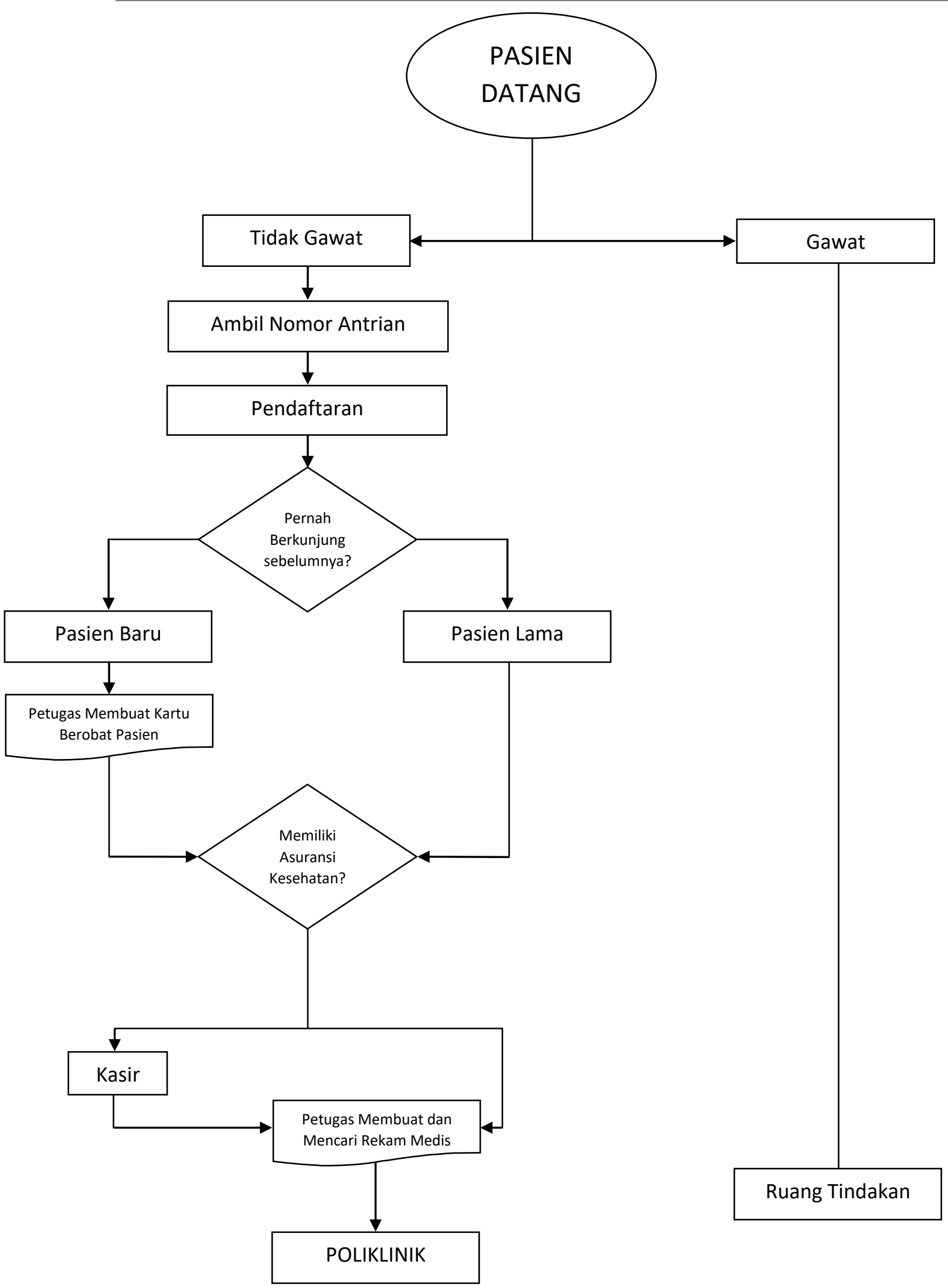

Gambar 1. Alur Penerimaan Pasien Puskesmas Sudi. 


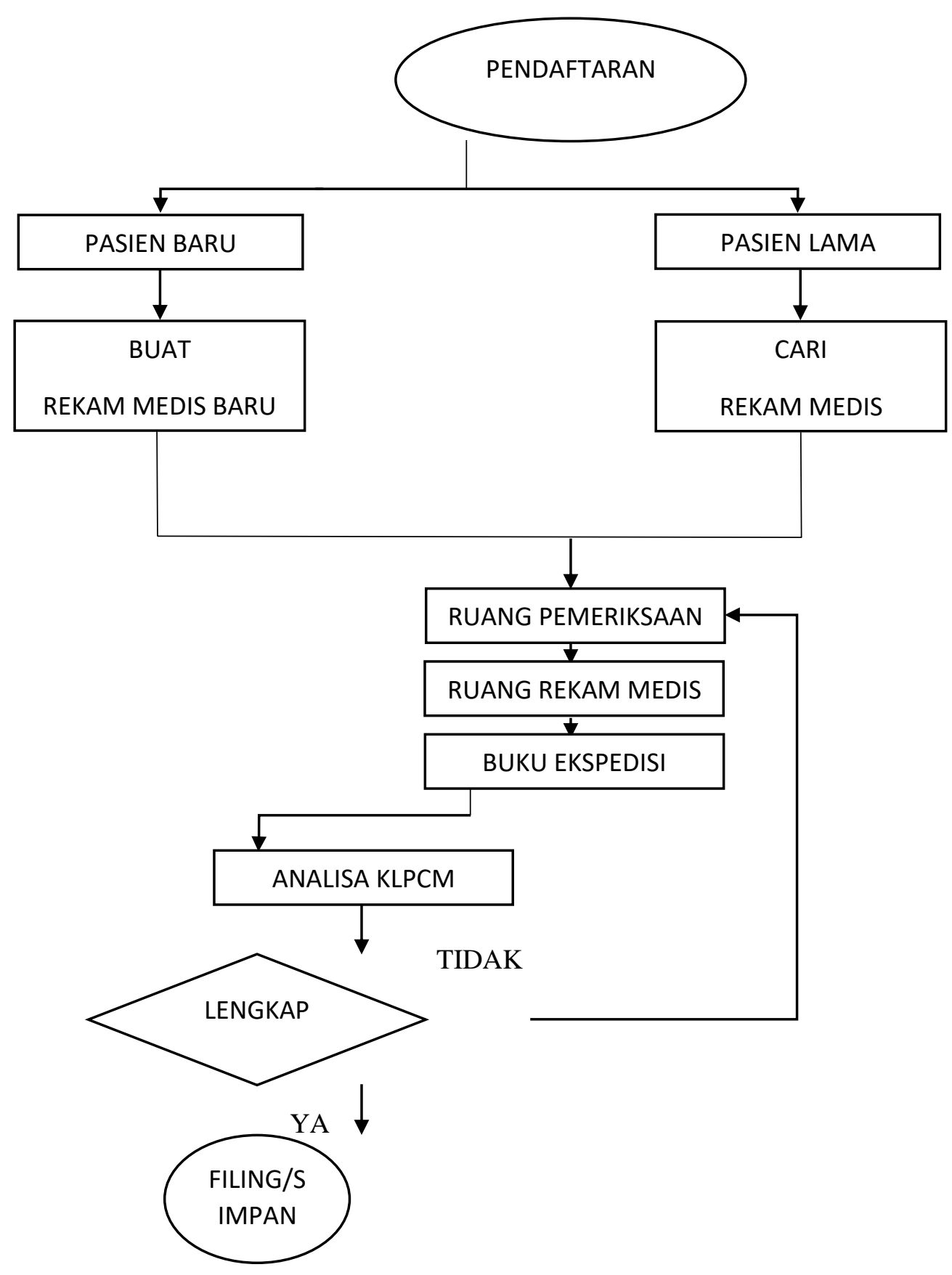

Gambar 2. Alur Petugas Rekam Medis.

Berikut adalah Identifikasi alternatif solusi dari unsur 5M yang dibuat oleh peneliti:

Tabel 1. Identifikasi Alternatif Solusi 


\section{Unsur 5M}

Man

Money

Method

Material

\section{Permasalahan}

Kurangnya komunikasi antara perekam medis dengan kepala puskesmas.

Kurangnya pemahaman pasien atas pentingnya KIB

Tidak ada anggaran untuk
pengaplikasian KIB

KIB masih berbentuk kertas sehingga dianggap kurang penting oleh pasien

Kurangnya pengetahuan pasien atas alur pendaftaran

\section{Solusi}

Petugas rekam medis mengajak diskusi atau berkomunikasi yang berkaitan dengan alur penerimaan pasien

Petugas Rekam Medis membuat kebijakan mengenai Kartu Indeks Berobat (KIB)

Pengajuan anggaran untuk mengaplikasikan kartu berobat yang lebih tebal.

Membuat kartu dengan yang berbahan tebal seperti kartu jaminan kesehatan lain nya sehingga akan mudah dingat oleh pasien

Petugas rekam medis membuat alur penerimaan dengan alur yang lebih mudah dimengerti pasien dan memberikan pemahaman kembali kepada pasien

Berdasarkan data kunjungan pasien dari bulan April-Mei 2021, maka peneliti membuat identifikasi sebagai hasil penelitian menggunakan persentase jumlah kunjungan pasien yang tidak membawa kartu berobat di Puskesmas Sudi Kab. Bandung sebagai berikut:

Tabel 2. Identifikasi Persentase Kunjungan Pasien

\begin{tabular}{l|lllll} 
NO & $\begin{array}{l}\text { TGL/BLN } \\
\text { KUNJUNGAN } \\
\text { PASIEN }\end{array}$ & $\begin{array}{l}\text { JUMLAH } \\
\text { PASIEN }\end{array}$ & $\begin{array}{l}\text { MEMBAWA } \\
\text { KIB }\end{array}$ & $\begin{array}{l}\text { TIDAK } \\
\text { MEMBAWA } \\
\text { KIB }\end{array}$ & PERSENTASE \\
\hline $\mathbf{1}$ & 05/April 2021 & 60 & 18 & 42 & $30 \%: 70 \%$ \\
$\mathbf{2}$ & $06 /$ April 2021 & 37 & 14 & 23 & $38 \%: 62 \%$ \\
$\mathbf{3}$ & 12/April 2021 & 54 & 16 & 38 & $30 \%: 70 \%$ \\
$\mathbf{4}$ & 13/April 2021 & 34 & 12 & 22 & $35 \%: 65 \%$ \\
$\mathbf{5}$ & 19/April 2021 & 67 & 20 & 47 & $30 \%: 70 \%$ \\
$\mathbf{6}$ & 20/April 2021 & 37 & 13 & 24 & $35 \%: 65 \%$ \\
$\mathbf{7}$ & 26/April 2021 & 17 & 8 & 9 & $47 \%: 53 \%$ \\
$\mathbf{8}$ & 27/April 2021 & 24 & 11 & 13 & $46 \%: 54 \%$
\end{tabular}




\begin{tabular}{l|lllll}
$\mathbf{9}$ & 03/Mei 2021 & 67 & 30 & 37 & $45 \%: 55 \%$ \\
$\mathbf{1 0}$ & 04/Mei 2021 & 36 & 19 & 17 & $53 \%: 47 \%$ \\
$\mathbf{1 1}$ & 10/Mei 2021 & 49 & 19 & 30 & $39 \%: 61 \%$ \\
$\mathbf{1 2}$ & 11/Mei 2021 & 26 & 10 & 16 & $39 \%: 61 \%$ \\
$\mathbf{1 3}$ & 17/Mei 2021 & 60 & 27 & 33 & $45 \%: 55 \%$ \\
$\mathbf{1 4}$ & 18/Mei 2021 & 56 & 40 & 16 & $71 \%: 29 \%$ \\
$\mathbf{1 5}$ & 24/Mei 2021 & 59 & 33 & 26 & $56 \%: 44 \%$ \\
$\mathbf{1 6}$ & 25/Mei 2021 & 38 & 15 & 23 & $40 \%: 60 \%$ \\
$\mathbf{1 7}$ & 31/Mei 2021 & 79 & 39 & 40 & $49 \%: 51 \%$
\end{tabular}

Dalam pelaksanaan pelayanan penerimaan pasien rawat jalan di Puskesmas Sudi menerapkan sistem penomoran secara Unit Numbering System, yaitu sistem penomoran dimana sistem ini memberikan satu nomor rekam medis pada pasien berobat jalan, nomor rekam medis ini dapat dipergunakan untuk semua pelayanan kesehatan yang ada difasilitas pelayanan rawat jalan.

Kelebihan sistem penomoran ini adalah informasi klinis yang dapat berkesinambungan karena semua data dan informasi mengenai pasien dan pelayanan yang diberikan terdapat dalam satu berkas. Sedangkan kekurangannya yaitu pelayanan akan lebih lama karena berkas akan dicarikan terlebih dahulu, setelah berkas ditemukan pasien baru akan mendapatkan pelayanan.

Selain itu, Puskesmas Sudi menerapkan sistem penyimpanan secara family folder, yang merupakan sarana untuk merekam (menyimpan) data keluarga dan data individu keluarga. Data keluarga meliputi komponen rumah sehat. Dan data individu anggota keluarga mencantumkan karakteristik individu meliputi: umur, jenis kelamin, alamat dan lain-lain.

Namun dalam pelaksanaan pelayanan kesehatan pasien sering tidak membawa kartu berobat yang telah diberikan petugas sebelumnya, karena kurang pahamnya pasien dalam kegunaan KIB.

Maka dari itu dibutuhkannya tulisan pasien wajib membawa kartu berobat untuk menerima pelayanan kesehatan dengan membuat alur pendaftaran pasien yang lebih mudah dipahami pasien. Dengan adanya alur pendaftaran maka diharapkan pasien mengetahui bagaimana alur pelayanan di Puskesmas Sudi. Selain itu, dengan letak alurnya harus diperhatikan, sebaiknya disimpan di depan kaca tempat tunggu pasien, sehingga pasien yang sedang menunggu giliran pendaftaran akan membaca terlebih dahulu sebelum masuk untuk mendaftar.

Kartu berobat merupakan alat yang sangat diperlukan untuk pencarian nomor rekam medis untuk pasien lama. Karena di Puskesmas sudah menggunakan pendaftaran online dengan SIMPUS namun masih menggunakan rekam medis manual, maka jika pasien tidak membawa kartu berobat akan dicarikan sesuai nama KK dalam komputer, jika sudah ada namun belum tertera nomor rekam medis maka petugas harus memberikan nomor baru kepada pasien sehingga seringkali terjadi data ganda pada identias pasien dalam nomor yang berbeda. Seharusnya petugas rekam medis membuat 
Buku Indeks atau Kartu Indeks Utama Pasien (KIUP) untuk memudahkan petugas mencari nomor rekam medis untuk pasien lama.KIUP merupakan kunci petunjuk lokasi rekam medis, salah satu alat (tool) yang digunakan untuk membantu pencarian berkas rekam medis didalam rak penyimpanan.

Berikut adalah hasil persentase yang menunjukan hasil jumlah pasien yang tidak membawa KIB saat melakukan pendaftaran di Puskesmas Sudi.
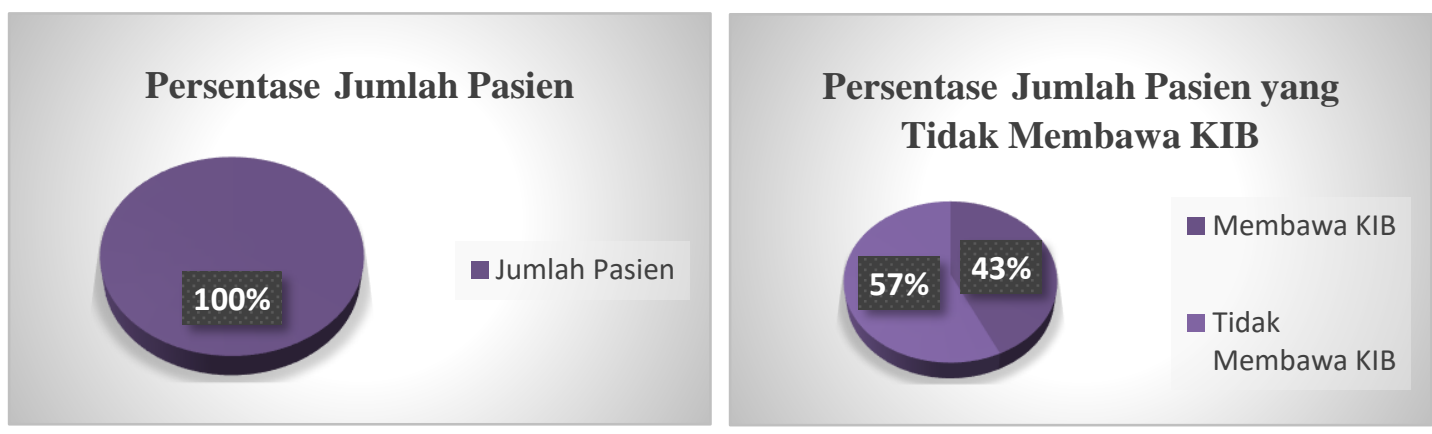

Berdasarkan hasil penelitian peneliti menemukan beberapa faktor penyebab pasien tidak membawa KIB di Puskesmas Sudi. Dilihat dari faktor manusianya yaitu sebagai berikut:

1. Kurangnya komunikasi anatara perekam medis dengan kepala puskesmas, sehingga kurang di perhatikannya pelayanan di bagian penerimaan pasien oleh petugas puskesmas.

Salah satu komponen untuk membentuk sistem informasi yang baik adalah komponen manusianyayang mengatur dan tata cara menggunakan sistem

Sehingga bertujuan untuk memperbaiki dan menyusun suatu sistem secara optimal untuk waktu yang akan datang. Agar pelayanan dibagian pendaftaran berjalan dengan baik, maka diperlukan komunikasi yang baik dengan kepala puskesmas karena dengan adanya dukukungan dari kepala puskesmas maka diharapkan pelayanan rekam medis di Puskesmas Sudi bejalan dengan lancer.

2. Kurangnya pemahaman pasien atas penjelasan petugas.

Berdasarkan hasil wawancara dengan salah satu pasien yang tidak membawa KIB pada saat melakukan pendaftaran di bagian rawat jalan di Puskesmas Sudi, dapat disimpulkan bahwa pasien belum memahami pentingnya KIB saat melakukan pendaftaran rawat jalan, pasien menyebutkan bahwa menganggap kartu tersebut hanya berlaku untuk satu anggota keluarga (individu), menganggap bahwa kartu tersebut tidak diperlukan jika memiliki kartu jaminan kesehatan.

Berdasarkan hasil wawancara dengan petugas rekam medis menyebutkan bahwa, petugas sering mengingatkan namun pasien tetap tidak membiasakan membawa kartu berobat tersebut yang sering beralaskan lupa.

Maka dari itu peneliti menemukan faktor prnyebab terjadinya pelayanan penerimaan pasien rawat jalan dibagian pendaftaran tidak efektif yaitu kurangnya sarana dan prasarana yang kurang mendukung untuk pengoperasian KIB yang mulai dari bentuk kartu dan penyajian kartu. 
Berdasarkan pengidentifikasian solusi maka peneliti memilih solusi yang peneliti anggap solusi tersebut adalah solusi yang terbaik untuk menyelesaikan permasalahan untuk menyelesaikan permasalahan tidak efektifnya pelayanan pendaftaran pasien di Puskesmas Sudi adalah sebagai berikut:

1. Diadakannya alur pendaftaran yang lebih mudah dipahami pasien sebagai acuan pasien untuk berobat.

Dengan diadakannya alur pendaftaran untuk prosedur penerimaan pasien baru dan lama dengan alur yang lebih mudah dipahami ini diharapkan pasien akan lebih tertib dan juga konsisten dalam pelaksanaan pendaftaran dengan selalu membawa KIB saat mendaftar.

2. Memulai komunikasi dengan kepala puskesmas untuk mencapai pelayanan rekam medis yang efektif.

Dengan memulai komunikasi dengan kepala puskesmas diharapkan kepala puskesmas akan lebih memperhatikan pelayanan yang diberikan dan memberikan solusi bagi pelayanan dibagian pendaftaran pasien.

3. Memberikan peringatan bagi pasien setiap berkunjung, memberi tahu agar selalu membaca tata tertib, peraturan pelayanan rawat jalan di Puskesmas Sudi.

Dengan memberikan peringatan pasien akan lebih mengingat bahwa kartu berobat tersebut sangat penting bagi pelayanan kesehatan pasien dan akan lebih memperhatikan setiap tata tertib yang ada di Puskesmas Sudi.

4. Mengoreksi bagian pendaftaran pada aplikasi sistem pelayanan (SIMPUS) sehingga nomor rekam medis tidak sulit untuk ditemukan.

Dengan menggunakan aplikasi SIMPUS maka akan memudahkan petugas rekam medis untuk menemukan nomor rekam medis apabila nomor rekam medis saat diberikan kepada pasien langsung di input ke dalam sistem, aplikasi tersebut sama halnya dengan kegunaan KIUP dan buku indeks untuk memudahkan petugas menemukan nomor rekam medis.

\section{Kesimpulan}

Faktor yang menjadi pelayanan tidak efektif dibagian pendaftaran yaitu dengan adanya beberapa masalah pada proses penerimaan pasien rawat jalan ada beberapa permasalahan yaitu banyaknya pasien yang tidak membawa kartu berobat, tidak pahamnya akan pentingnya alur pendaftaran pasien rawat jalan, sehingga tidak memperhatikan apa saja syarat untuk berobat rawat jalan di Puskesmas Sudi.Berdasarkan unsur 5M faktor yang menjadi penyebab permasalahan tidak efektifnya pelayanan penerimaan pasien rawat jalan di Puskesmas Sudi diantaranya yaitu faktor man (manusia)dan method (metode).Dilihat dari hasil identifikasi dari aspek manusia (Man) yaitu kurangnya komunikasi antara petugas rekam medis dengan kepala puskesmas, dan sumber daya manusianya adalah kurangnya tenaga kesehatan untuk mengoprasikan bentuk KIB baru.Jika dilihat dari aspek cara pelaksanaan (Method) yaitu kurangnya pemahaman kepada pasien, kurangnya petunjuk alur pendaftaran pasien.Solusi untuk menyelesaikan permasalahan ini untuk menghindari terjadinya pelayanan terhambat oleh pasien yang tidak membawa kartu berobat, yaitu dengan cara membuat buku indeks dan Kartu Indeks Utama (KIUP) supaya memudahkan petugas rekam medis untuk melakukan pencarian nomor rekam medis pasien. Dan saran untuk menyelesaikan permasalahan ini adalah sebaiknya membuat alur pendaftaran pasien yang lebih mudah dipahami oleh pasien

\section{Referensi}

Dr.Drs. I Wayan Suwendra, S. M. (2018). Metodologi Penelitian Kualitatif. Jl.Raya DarmasabaLukluk,Bandung, Bali 80353: Nilacakra. 
Hetty, I. (2018). Manajemen Unit Kerja. Yogyakarta: Deepublish.

I Putu Sudayasa, R. P. (2019). Penguatan dan Inovasi Pelayanan Kesehatan. Kendari: UHO EduPress.

Mary A. Nies, M. M. (2019). Keperawatan Kesehatan Komunitas dan Keluarga. Singapore: ELSEVIER.

Mathar, I. (Oktober 2018). Managemen Informasi Kesehatan (Pengelolaan Dokumen Rekam Medis). Yogyakarta: DEEPUBLISH.

Sabran, A. D. (2021). Buku Ajar Praktik Klinis Rekam Medis. Keluharahan Blabak, Kecamatan Pesantren, Kota Kediri: CV.Pelita Medika.

Santy Irene Putri, S. M. (2019). SISTEM INORMASI KESEHATAN. Ponorogo: Uwais Inspirasi Indonesia.

Suharto, S. (2019). Kajian Survey Kepuasan Layanan publik dan Kebijakan Pemerintah Daerah. Ds.Sidoharjo, Kec.Pulung, Kab.Ponogoro: Uwais Inspirasi Indonesia. 